\author{
М. Бліхар, \\ доктор юридичних наук, доцент, \\ професор кафедри адміністративного та інформаційного права \\ Навчально-наукового інституту права, психології та інноваційної освіти \\ Національного університету «Львівська політехніка»
}

\title{
АДМІНІСТРАТИВНО-ПРАВОВІ ЗАСОБИ ЗАХИСТУ ПУБЛІЧНОГО ІНТЕРЕСУ
}

Правові засоби захисту публічних інтересів за допомогою адміністративного судочинства зумовлені вже самим змістом адміністративного та адміністративно-процесуального права, оскільки публічний інтерес покладено в основу системи адміністративного права, яке було сформоване з огляду на потребу правового унормування публічних інтересів.

Особливості адміністративно-правового захисту публічного інтересу вивчено через співвідношення «публічного» і «приватного» та визначено вплив адміністративно-правового механізму на правильну ідентифікацію публічного інтересу, обгрунтовано значення дієвих правових механізмів захисту публічного інтересу у правовій системі.

Суть, зміст, види та форми публічного інтересу у системі адміністративного права досліджено у працях багатьох учених-правознавців. Зокрема, можна виокремити наукові роботи провідних вітчизняних правознавців-адміністративістів: Т.О. Коломоєць, Т.О. Мацелик, Р.С. Мельника, В.О. Рядінської, М.О. Стефанчука та ін. Поняття та зміст окремих способів адміністративно-правового захисту досліджено у працях О.М. Бандурки, 3.С. Варналія, О.В. Волкович, В.В. Галунька, Я.В. Греци, М.В. Кова- льової, Т.М. Кравцової, О.В. Кужель, В.І. Курила, В.К. Мамутової, В.Л. Мусіяки, Є.В. Петрова, І.М. Риженко, О.П. Рябченко, Н.О. Саніахметової та ін. Проте цілісне бачення адміністративно-правового механізму забезпечення й захисту прав суб'єктів публічного інтересу досліджено не досить.

Проблема співвідношення інтересів сторін у категоріях «приватний суспільний - публічний - державний» у суспільно-правових відносинах формувалася у праві досить давно. Ще в римському праві вирізняли публічний як загальний і більш широкий інтерес для суспільства та суто приватний, тобто пов'язаний 3 конкретною особою.

Поступово з формуванням приватного права сформувалося й публічне право як система правових норм, що покликані регламентувати суспільні відносини задля визначення основ соціально-правового управління державою, встановлення принципів функціонування держави, а згодом і правової держави, іï органів та держслужбовців.

Сучасне право, основним призначенням якого вважається забезпечення природних прав і свобод людини та громадянина, визнає правовим будь-який адміністративно-пра- 
вовий акт, якщо він відповідає природному праву й узгоджується з ним, а отже, основним напрямом глобальної діяльності суб'єктів публічного адміністрування, з погляду парадигми природного праворозуміння, є пріоритет забезпечення охорони прав і свобод людини [1, с. 34].

3 іншого боку, важливість забезпечення публічного інтересу проявляється через забезпечення охорони прав і свобод людини, оскільки дотримання публічного інтересу в розумінні його важливості для суспільства неодмінно сприятиме реалізації та захисту приватних інтересів конкретного індивідуума через певну сферу дотримання і здійснення публічного інтересу.

Так, наприклад, дотримання публічного інтересу в забезпеченні правопорядку та дотримання законності у суспільстві відповідає приватному інтересу будь-якого громадянина через забезпечення стабільності, правопорядку у суспільстві й особистої безпеки окремої людини. Публічний інтерес в організації освіти населення та інших соціальних сферах у державі відповідає приватним інтересам кожного члена суспільства в отриманні соціальних, освітніх чи інших послуг належної якості.

Навіть якщо така сфера, як сплата податків, на перший погляд, «суперечить» бажанню і приватному інтересу окремої людини, підприємця, публічний інтерес у забезпеченні державного бюджету й можливості використання отриманих коштів через податкову систему дозволяють усім громадянам без винятку користуватися суспільними благами, які гарантовані державою, ідеться про освітні послуги, пенсійне забезпечення, медичні послуги, а також загальноважливі функції соціального захисту, забезпечення правопорядку, екологічної безпеки, вирішення питань захисту національної безпеки, територіальної цілісності, спільні інтереси територіальних громад сіл, селищ і міст, громадського порядку та обороноздатності країни тощо.

Тому потрібно шукати розумний компроміс між приватним, державним і публічним інтересами для забезпечення розвитку правової демократії в державі в тому сенсі, щоб приватний інтерес не поглинувся повністю державним чи публічним, оскільки державний чи публічний інтерес, як правило, має більше правових і владних важелів для своєї реалізації. Це можливо лише після суспільного їхнього узгодження та закріплення правового балансу і статусів внаслідок активної взаємодії суб'єктів суспільних відносин на основі правової рівності.

Очевидно, що правовий баланс різних суб'єктів суспільних відносин може змінюватися залежно від ситуації, тобто потрібно враховувати, що паритет публічного інтересу, який гарантуе можливість додержання найбільш прийнятного для всіх сторін відносин і з урахуванням особистої й колективної вигоди та ефективності прийнятих рішень для захисту своїх інтересів сторонами цих суспільних відносин. Як вказує В.М. Кармаліта, так можна сформувати систему визначених правових можливостей, що проявлятиметься в консолідованому правовому акті сторін правовідносин, у якому буде відображено баланс інтересів їніх учасників [2, с. 10].

При цьому суб'єкт суспільних відносин у процесі реалізації свого права і свободи може діяти як завгодно і доти, доки його діяльність чи бездіяльність не заторкує публічного інтересу. На думку P.I. Раімова, публічним інтересом можна вважати будь-який приватний інтерес, під час здійснення якого будуть реалізовані певні права і свободи, щодо забезпечення яких держава має зобов'язання [3, с. 119]. Такий погляд на визначення публічного інтересу співвідноситься 3 поняттям інтересу держави й публічної влади. Тобто публічний інтерес стає за своєю суттю відображенням інтересу державного, як осо- 
бливої форми організації суспільства, яка спрямовує суспільно-правову реалізацію прав і свобод передусім на самозбереження спільноти. У цьому аспекті, як зазначає С.В. Савченко, в узагальненому вигляді публічний інтерес слугує забезпеченню цілісності і стійкого функціонування суспільства, має особливий порядок реалізації та імперативний характер, на його захисті стоять різні державно-владні інститути, а його реалізація завжди відбувається в інституційних формах [4, с. 522].

Очевидно, що саме держава та іï владні органи, а також публічна адміністрація виступають основними суб'єктами забезпечення публічного інтересу і здійснюють це через свої владні функції в конкретній сфері щодо конкретного правовідношення, зокрема через органи законодавчої, виконавчої чи судової влади.

Діяльність державних органів управління підпорядковується суворому правовому стандарту, оформленому у відповідних правових актах. Такий правовий регламент діяльності державних органів покликаний забезпечити загальний нормальний добробут населення, права і свободи людей, суспільне життя і безпеку, успішну діяльність держави загалом.

Варто зауважити, що від початку 90-х років XX ст. у вітчизняній правовій науці розвиваються доктрини публічного права, теорія публічних та приватних інтересів різноманітних суб'єктів права. У межах розвитку концепції людиноцентризму, в основі якої - пріоритетність принципу верховенства права в публічно-правових відносинах у сучасній правовій державі, в теорії адміністративного права дедалі активніше відбувається перехід від поняття «державне управління» до поняття «публічне адміністрування».

Значний вплив мали сучасні європейські правові школи, зокрема німецька теорія адміністративного права. Тож важливо вивчати іï правові інститути, такі як публічне управління, адміністративні послуги, адміністративні процедури.

Сучасна правова наука у поняття публічного інтересу, як правило, об'єднує державні, суспільні та місцеві (територіальні) інтереси [5, с. 151152]. У цьому аспекті важливо розуміти, що саме дотримання публічного інтересу є більш узагальненим і широким стосовно забезпечення інтересів усіх учасників суспільно-правових відносин. Так, поняття «публічний інтерес» є більш об'ємним, ніж «державний інтерес», хоча саме держава покликана забезпечувати захист та узгодження інтересів усіх членів суспільства. Саме це має забезпечувати публічне право, основою якого $є$ категорія публічного інтересу.

Вивчення публічного інтересу вітчизняними правознавцями розширюється не тільки відмінностями, а й важливістю розгляду особливостей поєднання публічних та приватних інтересів і в приватному, і в публічному праві [6, с. 72]. Адже не завжди суспільний інтерес можна трактувати як публічний. Як вважає А.А. Нечай, публічні інтереси мають підтримуватися діяльністю держави (чи адміністративно-територіальних одиниць) в особі відповідних органів влади [7, с. 34-36].

Згідно з теорією права, інтерес визнається публічним, якщо він $є$ спільним і його можна розглядати як узагальнення особистих, групових інтересів, без задоволення та реалізації яких неможливо, з одного боку, реалізувати приватні інтереси осіб, а $з$ іншого - важко забезпечити стабільність, цілісність та суспільний розвиток організацій, соціальних груп, держави, нації та суспільства загалом. А отже, як зазначає Д.О. Білінський, під час дослідження публічного інтересу насамперед важливо враховувати, що об'єднавчим аспектом для сукупності зацікавлених інтересів тут завжди будуть наявні зовні життєво важливі для всього суспільства потреби [8, с. 157-162]. 


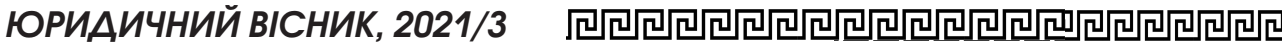

Водночас, як зауважує О.М. Вінник, в Україні простежується розбалансування приватних і публічних інтересів на користь приватного, що свідчить про недооцінювання, а інколи й повне ігнорування публічного інтересу та важливості суспільного блага на противагу індивідуальному чи приватному інтересу. Як наслідок, маємо порушення економічних інтересів у суспільстві на користь збагачення окремих осіб, зростання економічної злочинності, порушення екологічної безпеки, зубожіння більшої частини населення [10, с. 91]. На думку О.I. Чеписа, це стало можливим через неврахування важливості публічно-правових засад під час регулювання ринкових відносин, що відображено в якості прийнятих законодавчих та інших нормативно-правових актів, особливо на початку проведення економічних реформ [11, с. 261-265]. Часто це було зумовлене обгрунтуванням, що важливішим $€$ пріоритет приватного інтересу як основного чинника існування ринкової економіки, а відповідно, шкідливістю державного управління і надмірного державного регулювання. Проте часто саме під таким запереченням «ховалося» намагання використати не повністю сформоване правове поле українського законодавства для власного збагачення.

Розглядаючи місце та значення публічного інтересу в системі інтересів як певних цінностей, треба виходити з того, що пріоритетне значення і важливість цього інтересу для суспільства визначає суб'єкт (носій) публічного інтересу, тобто суспільство як органічне ціле. I цим пояснюється роль органів державної влади в публічно-правовому регулюванні механізмів забезпечення й регулювання цих правовідносин. А застосування постулатів теорії інтересів дає змогу побачити та виокремити предметний і юридичний зміст державних, суспільних, групових та приватних потреб, допомагає формувати основні ознаки адміністративного права щодо публічного процесу i характеризує публічно-правову сутність публічного інтересу.

Значущість праворегулятивної функції держави, яка не тільки скеровує реалізацію публічного інтересу особи та суспільства загалом у потрібному правовому напрямі, а й не дає окремим суперечностям перерости у соціальний конфлікт, захищає найбільш значущі і водночас найвразливіші інтереси суб'єкта публічного інтересу, забезпечуючи заодно баланс інтересів особистості, суспільства та самої держави, саме так проявляються функції держави.

Публічний інтерес - це інтерес соціальної спільноти, що визнається державою і забезпечується правом, а реалізація цього інтересу слугує гарантією існування та розвитку конкретної спільноти.

Як зауважує В.М. Кармаліта, найпоширенішим типом правового регулювання публічного інтересу зараз $€$ такий, що поєднує публічно-правове і приватноправове регулювання суспільних відносин у різних співвідношеннях [2, с. 161]. Адміністративний кодекс у цьому аспекті $€$ комплексним нормативно-правовим актом, у якому відображено правові норми приватноправового і публічно-правового характеру.

P.A. Калюжний, розглядаючи соціальний механізм вітчизняного законодавства щодо формування та реалізації державного управління, акцентує увагу на спрямуванні сучасної адміністративної правової політики у цій сфері на забезпечення передусім публічних інтересів. Це, на його думку, сприятиме поліпшенню правового регулювання відносин державної влади (зокрема, виконавчої) та інтересів громадян, а також запобігатиме прийняттю непродуманих актів управління, що можуть порушувати права чи свободи громадян [12, c. 90$]$. 


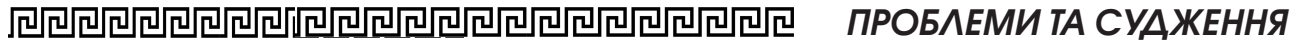

На наш погляд, саме соціальна зумовленість будь-якого публічного інтересу та визначення публічних засобів у механізмі адміністративно-правового регулювання правових актів виражаються в необхідності логічної узгодженості приватних i публічних інтересів для ефективного функціонування суспільних регуляторів у різних сферах суспільної діяльності. Адже межі застосування механізму реалізації публічного інтересу і визначають масштаб та обсяг, у яких допустиме використання публічно-владних важелів впливу у сфері адміністративного права задля забезпечення інтересів публічного характеру через певний правовий акт [13, с. 170-174].

Водночас варто пам'ятати про важливість постійного врахування балансу між приватним і публічним у забезпеченні інтересів сторін суспільно-правової дії, оскільки, як наголошує С.В. Савченко, саме складність, а то й відсутність можливості встановити і визначити відповідний баланс між публічними та приватними інтересами у разі здійснення правового регулювання суспільних відносин може спричинити гострі проблеми та конфлікти [4, с. 520].

Таким чином, публічний інтерес об'єктивно наявний у суспільстві, тобто передумовою для його існування $€$ необхідність встановлення пріоритетності природних потреб суспільства. Його задоволення має велике значення для всього суспільства як сукупності (широкого кола) суб'єктів чи значного кола учасників суспільно-правових відносин, для яких він однаково цінний. Як правило, публічний інтерес визнається державою та закріплюється в нормах публічного права, насамперед у положеннях Kонституції України. Публічна адміністрація та публічне управління є єдиним суб'єктом, який має правові компетенції щодо забезпечення публічного інтересу, що покладається на чинні адміністративно-правові акти.
Об’єктивний характер публічного інтересу зумовлює необхідність створення у правовій системі відповідного синергетичного механізму, тобто механізму ї узгодження стосовно всіх учасників цього соціально-правового конфлікту.

Соціально-правовий механізм формування та реалізації державного управління публічним інтересом може бути представлений низкою взаємопов'язаних суспільно-правових актів, що опосередковані державою чи публічним управлінням як суб'єктом управління: публічні потреби - публічні інтереси публічна мета - рішення публічного управління чи адміністративно-правових установ у разі судового розгляду - дії на дотримання публічного інтересу або виправлення порушення публічного інтересу - результати реалізації публічного інтересу.

Розвиток вітчизняного законодавства, зокрема адміністративного, має спрямовуватися на врахування i забезпечення публічних інтересів, що в підсумку сприятиме поліпшенню правового регулювання відносин органів публічного управління і громадян / частини громадянського суспільства чи суспільства загалом, а також протидіяти прийняттю непродуманих актів публічного управління, які не повністю задовольняють інтереси суспільства.

У такому разі в контексті обговорення проблеми захисту публічного інтересу йдеться про охоронну функцію адміністративного права, оскільки сучасна теорія адміністративного акта забезпечує дотримання публічного інтересу через можливість судового оскарження будь-якого акта управління, якщо він перешкоджає реалізації прав і свобод фізичних чи юридичних осіб.

Можливість захисту публічного інтересу шляхом адміністративно-правового регулювання. Можна стверджувати, що правові акти публічного управління створюють підставу для формування системи адміністративної 
юстиції - важливого правового засобу усунення помилок у сфері адміністративного правоутворення через врахування численних публічних інтересів. Тут ідеться про позитивну управлінську діяльність, яка спрямована на вирішення публічного інтересу через здійснення публічного управління з дотримуванням прав та обов'язків усіх членів суспільства чи соціальних груп.

Стаття присвячена дослідженню значення узгодження державного, суспільного, приватного та індивідуального інтересів у різних сферах суспільного життя у контексті розвитку України як правової $i$ демократичної держави. Обтрунтовано, що найчастіше стикування цих інтересів відбувається у формі конфліктного протистояння зацікавлених сторін, оскільки вони відстоюють взаємозаперечувальні інтереси в певних суспільних відносинах $у$ площинах «публічний - приватний», «публічний - суспільний» чи «публічний - державний». Запропоновані способи правового розв'язання конфлікту, що обтрунтовують необхідність вирішення питання захисту публічного інтересу як способу задоволення інтересів, прав, дотримання обов'язків усіма зацікавленими сторонами та суспільством загалом. отне, доведено, що питання співвідношення публінного і приватного інтересів у різних видах суспільних відносин постає особливо актуальним у час, коли правова система України перебудовується на максимальне узгоджене врахування інтересів усіх сторін изих відносин та їх відображення в історичному розвитку і проиесі становлення правової системи демократичної держави. В межах правової практики наголошено на важливості правової організаціі захисту публічного інтересу всіх учасників суспільних відносин, зокрема й правовідносин, спонукає державу до необхідності врегулювання та адміністративно-право- вого забезпечення иього ванливого сегмента системи права в Україні. Значна частина правового врегулювання питань захисту публічного інтересу належить до сфери адміністративного права.

У контексті проведеного досліднення з’ясовано, шо принципи верховенства права й визначення людини як найвищої соціальної цінності у суспільстві закріплені в Конституиіі України, визначення шляху розвитку України як соиіальної держави стало підгрунтям для перегляду правових доктрин $i$ механізмів захисту інтересів иленів суспільства. У цьому розумінні публічний інтерес виступає як спосіб задоволення різних суспільних потреб: $i$ публічних, $i$ приватних, що сприяе виникненню, розвитку та еволюиї суспільних відносин, важливих для всього суспільства. Сторони, щзо впливають на формування публінного інтересу, можуть мати різний правовий статус, тобто сукупність прав та обов'язків, що впливатиме на різні аспекти забезпечення функиіонування та реалізації цьього публінного інтересу. Врешті обтрунтовано тезу, відповідно до якої у зв'язку з нормативною невизначеністю категоріі «nублінний інтерес» в адміністративному праві немає дієвих механізмів його реалізації й захисту, що унеможливлюе здійснення функиіі участі громадськості в ухваленні управлінських рішень та контролі за ї виконанням.

Ключові слова: адміністративні правовідносини, публічний інтерес, публічне управління, публічна адміністрація, державне управління, виконавча влада.

Blikhar M. ADMINISTRATIVE AND LEGAL MEANS OF PROTECTION OF PUBLIC INTEREST

The article is devoted to the study of the importance of coordination of state, public, private and individual 
interests in various spheres of public life in the context of the development of Ukraine as a legal and democratic state. It is substantiated that most often the collision of these interests occurs in the form of conflict of interest of stakeholders, as they defend conflicting interests in certain social relations in the planes "public - private", "public - public" or "public - state". Proposed ways of legal resolution of the conflict, which justify the need to address the issue of protection of the public interest as a way to satisfy the interests, rights, responsibilities of all stakeholders and society as a whole. Thus, it is proved that the question of the ratio of public and private interests in different types of public relations is especially relevant at a time when the legal system of Ukraine is restructured to take into account the interests of all parties and their reflection in the historical development and legal system of a democratic state. Within the framework of legal practice, the importance of the legal organization of protection of the public interest of all participants in public relations, including legal relations, emphasizes the need for regulation and administrative and legal support of this important segment of the legal system in Ukraine. Much of the legal regulation of public interest belongs to the sphere of administrative law.

In the context of the study, it was found that the rule of law and the designation of man as the highest social value in society, enshrined in the Constitution of Ukraine, and defining the development of Ukraine as a welfare state became the basis for revising legal doctrines and mechanisms to protect the interests of society. In this sense, the public interest acts as a way to meet various social needs, both public and private, which contributes to the emergence, development and evolution of social relations important to society as a whole. The parties influencing the formation of the public interest may have different legal status, i.e. a set of rights and obligations that will affect different aspects of ensuring the functioning and realization of this public interest. Finally, the thesis is that due to the regulatory uncertainty of the category "public interest" in administrative law there are no effective mechanisms for its implementation and protection, which makes it impossible to exercise public participation in management decisions and control their implementation.

Key words: administrative legal relations, public interest, public administration, public administration, public administration, executive power.

\section{Література}

1. Адміністративне право України : навчальний посібник. Т. 1: Загальне адміністративне право / В.В. Галунько, B.I. Курило, С.О. Короєд та ін. ; за ред. В.В. Галунька. Київ : Iн-т публічного права, 2015. $180 \mathrm{c}$.

2. Кармаліта В.М. Приватний $i$ публічний інтерес у системі податкових правовідносин : монографія. Хмельницький : ФОП Мельник А.А., 2019. 328 с.

3. Раімов P.I. Забезпечення публічного інтересу як принци адміністративно-правового регулювання діяльності суб'єктів природних монополій. Вісник Південного регіонального центру Національної академії правових наук України. Адміністративне право та процес, фінансове право, інформаційне право. 2019. № 19. C. 115-122.

4. Савченко С.В. Співвідношення приватних $i$ публічних інтересів: досвід України. Форум права. 2013. №3.C.520-528.URL:http: / / nbuv.gov.ua / UJRN/FP_index.htm_2013_3_87.

5. Гетманиев Д.О. Щодо забезпечення публінного інтересу для фінансового права. Часопис Київського університету права. 2011. № 4. С. 150-153.

6. Банчук О. Публічне $i$ приватне право: історія українських вчень та сучасність. Київ: Конус-Ю, 2008. $184 \mathrm{c}$.

7. Нечай А.А. Актуальні питання фінансового права: правові основи публіч- 


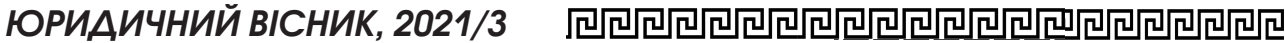

них накопичувальних фондів : монографія. Чернівиі : Рута, 2004. 376 с.

8. Білінський Д. Публічний інтерес як вихідна засада структурування фінансової системи. Вісник Національної академії правових наук України. 2013. № 3 (74). C. 157-162.

9. Блixap M.M. Public administration and management: modern scientific discussions : колективна монографія. Riga : Izdevnieciba "Baltija Publishing", 2020. $300 \mathrm{C}$.

10. Вінник O.M. Теоретичні аспекти правового забезпечення реалізації публічних $i$ приватних інтересів у господарських товариствах : дис. ... д-ра юрид. наук. Київ, 2004.
11. Непис O.I. Значення приватних mа публічних інтересів для формування ициільного права. Науковий вісник Ужгородського університету. Сер. «Право». 2010. Bun. 13. С. 261-265.

12. Калюжний P.А. Публічний інтерес у адміністративному праві. Наиіональна академія внутрішніх справ України. URL: https://er.nau.edu.ua/bitstream / NAU / $26547 / 1$ /.

13. Кубко А.Е. Засоби реалізаціi публічних інтересів у цивільному праві України: деякі методологічні аспекти. Часопис Київького університету права. 2010. № 3. С. 170-174. URL: ht t p: / / kul.kiev.ua / images/ chasop/2010_3/170.pdf. 